\title{
Crop Establishment SIMulator: A Qualitative Aggregative Model to Predict the Role of Phytobiomes on Field Crop Establishment
}

\author{
Jay Ram Lamichhane, ${ }^{1, \dagger}$ Ming Pei You, ${ }^{2}$ Martin J. Barbettii, ${ }^{2}$ and Jean-Noël Aubertot ${ }^{1}$ \\ ${ }^{1}$ INRAE, Université Fédérale de Toulouse, UMR AGIR, F-31326 Castanet-Tolosan Cedex, France \\ ${ }^{2}$ UWA School of Agriculture and Environment and The UWA Institute of Agriculture, The University of Western Australia, Crawley, WA 6009, \\ Australia
}

Accepted for publication 26 July 2020.

\section{ABSTRACT}

The definition of phytobiomes can be transposed to any agroecosystem and applies to any phase of crop cycles. Here, we study the crop establishment phase using a generic modeling framework to assess the potential role of phytobiomes on field crop establishment. We first developed a generic model called Crop Establishment SIMulator (CESIM) that takes into account cropping practices, seed and seedling characteristics, seedbed components (physical chemical and biological), and weather, as well as their interactions. All these variables were integrated in a qualitative aggregative hierarchical network to predict the quality of field crop establishment. CESIM has 38 basic (input variables) and 20 aggregated (19 state variables and 1 output variable) attributes for a total of 58 attributes. The prediction quality of the model was evaluated for a dataset of 231 field observations across four states of Australia and experimental results obtained in the last 40 years. Accuracy of predictions of the final attribute (i.e., crop establishment) was $91 \%$ and explained $29 \%$ of variability of the dataset, as described by the quadratic weighted Cohen's к. CESIM represents a unique and original generic model capable of taking into account a large number of variables and their interactions to predict the quality of field crop establishment. This model is flexible, transparent, and user friendly and, therefore, is suitable both for academic and nonacademic users. CESIM can be used across a wide range of situations to perform not only the ex-ante assessment of potential establishment quality of a given crop but also ex-post assessment.

Keywords: agronomy, conceptual modeling, damping-off, management, postemergence damage, preemergence losses, seedbed components, seed germination, seedling blight, seedling emergence, soilborne pathogens
Crop establishment is the very beginning phase of a crop cycle that consists of three subphases: sowing-seed germination, seed germinationseedling emergence, and seedling emergence-early seedling growth (i.e., initial competition among plants) (Aubertot et al. 2020). Crop establishment is the most important phase of any crop cycle because the quality of crop establishment can directly affect crop productivity in

${ }^{\dagger}$ Corresponding author J. R. Lamichhane: jay-ram.lamichhane@inrae.fr

Funding: This work was partly supported by the FAST project (Faisabilité et Evaluation de Systèmes de Cultures Economes en pesticides en l'Absence répétée de Semences Traitées) funded by the French Agency for Biodiversity, by credits from the royalty for diffuse pollution, attributed to the funding of the Ecophyto plan; and Institut National Polytechnique of Toulouse (INPT) for providing a short-term visiting Professor grant that allowed M. J. Barbetti to come to France and work with J. R. Lamichhane and J.-N. Aubertot.

*The $\boldsymbol{e}$-Xtra logo stands for "electronic extra" and indicates that two supplementary tables and four supplementary figures are published online.

The author(s) declare no conflict of interest.

(C) 2020 The American Phytopathological Society terms of both quantity and quality (Arvidsson et al. 2014; Känkänen et al. 2011; Villalobos et al. 2016). For example, a poor quality of crop establishment leads to several direct and indirect negative consequences for farmers, including the need for resowing (additional costs), yield losses, and higher density of weeds, with further problems owing to increased weed seed bank in the soil (Lamichhane et al. 2018).

Crop establishment is affected by four major groups of drivers and their interactions; namely, seed and seedling characteristics, seedbed components (physical, chemical, and biological) weather, and cropping systems (Lamichhane et al. 2018). Several studies have been carried out to understand the role of different factors on the quality of field crop establishment. However, these studies focused either on abiotic factors (Constantin et al. 2015; Dürr and Aubertot 2000; Souty and Rode 1993) or biotic factors (Baker 1971; Burdon and Chilvers 1975; Grogan et al. 1980) and cropping practices (Farooq et al. 2006; Leoni et al. 2013), without taking into account their overall impact or interactions. Therefore, there is a need to adopt "a systems-level approach" for a better understanding of these factors, their interactions, and their overall impact on the quality of field crop establishment (Lamichhane and Aubertot 2018). This approach is consistent with the definition of phytobiomes, 
which consist of plants, their environment, associated micro- and macroorganisms, and their interactions (Leach et al. 2017), as reported in the Phytobiomes Roadmap (Anonymous 2016). The phytobiome concept, in turn, is fully consistent with the definition of agronomy, as provided by Sebillotte (1974), who viewed agronomy as "a systemic approach to agriculture" that led to the development of a more holistic direction considering the entire agroecosystem, with a particular attention to cropping systems. Therefore, from here on, we use the term phytobiomes to indicate all of these key determinants affecting crop establishment.

Experimental approaches and regional agronomic diagnoses in commercial fields can be used to understand the effect of phytobiomes on field crop establishment. Nevertheless, both of these processes are time consuming and resource intensive. In addition, the limit of these approaches is that only a few variables can be studied at a time. In contrast, modeling allows taking into account all key factors affecting crop establishment, by integrating them into the same system over time. In particular, mechanistic models that simulate seed germination, seedling emergence, and early seedling growth as functions of measured or estimated environmental variables seem to be the most promising approach to understand the quality of field crop establishment. However, mechanistic models are difficult to develop because they require a detailed knowledge of the system, by integrating all factors and their interactions (Forcella et al. 2000). This is especially true when studying the quality of field crop establishment, which is affected by a large number of factors and their interactions (Lamichhane et al. 2018). Several models have been developed and used to achieve this objective. However, all of them take into account only a few factors affecting field crop establishment (Finch-Savage et al. 2005; Jame and Cutforth 2004; Wang et al. 2009). The SIMPLE crop emergence model (Dürr et al. 2001) is the most robust mechanistic model developed so far to study the quality of crop emergence. However, this model does not take into account biotic factors affecting crop establishment (Lamichhane et al. 2017) and that our knowledge is not still advanced sufficiently to integrate this part into a mechanistic model. In addition, the SIMPLE model cannot benefit from expert knowledge. Development and use of simpler models that benefit from experimental and observational data, in addition to published scientific and technical literature, existing simulation models, and expert knowledge, may prove useful to predict the quality of field crop establishment.

In order to do so, we propose a generic modeling framework called Crop Establishment SIMulator (CESIM). This framework is very simple in the way the modeled system is described, despite its complexity and the number of factors and processes involved, which would be very difficult to address using a mechanistic approach. Such a framework has been successfully developed and tested to predict risks of pest development on crops as a function of cropping practices, and abiotic and biotic environment (Aubertot and Robin 2013; Robin et al. 2013). CESIM is based on a simple qualitative hierarchical aggregative approach to represent the effects of various factors affecting the quality of field crop establishment. The objectives of this study were threefold: (i) present the basic principles of CESIM, (ii) apply it to a concrete case as a proof of concept: simulation of establishment quality of subterranean clover (Trifolium subterraneum L.) in various Australian conditions, and (iii) present a sensitivity analysis of the model (i.e., measure how the model output reacts to changes in input or aggregated attributes) (Carpani et al. 2012) and assess its prediction quality.

\section{MATERIALS AND METHODS}

Basic principles of CESIM. Three subphases characterize the establishment phase of any crop; namely, seed germination, seedling emergence, and early seedling growth (Aubertot et al. 2020). A conceptual scheme of CESIM, where crop establishment is the output variable, is presented in Figure 1. This scheme is an adaptation of a previously published scheme (Lamichhane et al. 2018), where four different components-cropping systems, seed and seedling characteristics, and seedbed components (physical, chemical, and biological)—were the input variables while seed germination and seedling emergence were the output variable. However, because CESIM goes beyond the seedling emergence phase and considers the quality of crop establishment as its output variable, we integrated into this scheme a fourth component represented by animal pests, especially the vertebrate ones. This is because vertebrate pests are often responsible for postemergence damage of young seedlings (Dimitri et al. 2012; Firake et al. 2016; Nasu and Matsuda 1976). The term "cropping system" indicates "a set of management practices applied to a given, uniformly treated area, which may be a field, part of a field or a group of fields" (Sebillotte 1990). This includes many technical operations such as the choice of the crop sequence, cover cropping, cultivar, tillage or seedbed preparation practices, date, depth and density of sowing, and so on. The term "system" is used here because these technical choices are interdependent (Meynard et al. 2003). Crop establishment can be seen as the result of hierarchical interactions among these components and the environment.

Implementation of CESIM. The development of CESIM was implemented using the DEXi software (https://kt.ijs.si/MarkoBohanec/ dexi.html). The underlying approach (called the DEX method) initially aimed at qualitative hierarchical multiattribute decision modeling and support, where a complex decision problem was broken down into smaller and less complex subproblems (Bohanec 2003). In the field of agronomy, this tool was applied to the assessment of sustainability of agroecosystems (Craheix et al. 2015; Pelzer et al. 2012; Sadok et al. 2009). In addition, the DEXi software has also been used to implement qualitative simulation models focusing on pest management (Aubertot and Robin 2013; Robin et al. 2013, 2018). The subproblems are hierarchically structured into a tree of attributes that represents the "skeleton" of the model. Terminal nodes of the tree (i.e., leaves) or basic attributes represent input variables of the model, which must be specified by the user. The root node represents the main output; in our case, it is the quality of crop establishment. The root node and internal nodes of the model are aggregated attributes. All of the attributes in the model are qualitative (ordinal or nominal) and not quantitative variables. They take only discrete symbolic values usually represented by words. In the DEX method, the aggregation of values of the tree is defined by "utility functions" based on a set of "if-then" aggregation rules. Here, we renamed these functions "aggregating tables" because they are not related to the concept of "utility" in decision theory (Aubertot and Robin 2013).

CESIM structure. As for building any DEXi model (Bohanec 2003), CESIM was designed in three steps: (i) identification and organization of the attributes, (ii) definition of attribute scales, and (iii) definition of aggregating tables.

Identification and organization of the attributes. CESIM aims at predicting the quality of any crop establishment in a given field based on a range of input variables. The spatial scale considered is the field while the temporal scale considered is a single growing season. Nevertheless, some input variables include the entire crop sequence (up to the preceding crops) because it affects the seedbed physical, chemical, and biological characteristics. The hierarchical structure of the model is presented in Figure 2, which represents the breakdown of factors affecting the quality of crop establishment into specific explanatory variables, represented by lower-level attributes. CESIM has 58 attributes in total, including 38 basic and 20 
aggregated attributes. The 38 basic attributes represent input variables of the model and are presented as the terminal leaves of the tree. The levels of the basic attributes are aggregated into higher levels according to aggregating tables. The aggregated attributes are internal nodes, which represent state variables or the output variable of CESIM, and they are determined by lower-level basic attributes (Bohanec et al. 2007). The importance of some basic attributes may differ not only from one crop species to another but also within a given crop, depending on the growth phase considered. This means that some basic attributes will have a higher impact than others on the final output (i.e., the quality of crop establishment). For example, seedbed chemical components such as organic matter or inorganic nutrients do not have any impact on seed germination, which relies on seed reserves (autotrophic phase). In contrast, they markedly affect seedling growth, especially after emergence. Likewise, emergence losses due to soilborne animal pests can be more important for maize, oilseed rape, or sugar beet but less important for soybean or sunflower (BSV 2016; Furlan et al. 2020; Lamichhane et al. 2020a). Likewise, postemergence seedling damage due to vertebrate pests maybe very high for sunflower (Sausse et al. 2016) or soybean (Firake et al. 2016) but less relevant for wheat. Similarly, crop compensation capacity is high for crops such as soybean and wheat through ramification and tillering capacity. In contrast, crops such as maize or sunflower do not have this capacity and, thus, are exposed to higher pre- or postemergence failure. At the same time, the importance of the same basic attribute on the same crop may differ depending on production situations (Aubertot and Robin 2013). For example, a diversified cropping system is less favorable for soilborne pathogens to cause pre- or postemergence damping-off disease than monocropping or lessdiversified cropping systems (Abdel-Monaim and Abo-Elyousr 2012; Hwang et al. 2008; Lamichhane et al. 2017). Likewise, the risk of postemergence damage due to vertebrate pests depends on a number of factors, including the field, landscape and regional characteristics (Bayani et al. 2016; Sausse and Lévy in press). Therefore, none of the basic attributes can be omitted from the model structure due to the generic nature of CESIM. However, we excluded weeds because their impact on crop growth, development, and yield become important only after the crop establishment phase (provided that a crop is sown in weed-free conditions), when they are sufficiently developed to compete with crops for light and nutrients (Chauhan and Johnson 2011; Chauhan and Opeña 2013).

Definition of the attribute scales. The choice of ordinal or nominal scales for basic and aggregated attributes represents the second step of a DEXi model design. To this objective, sets of discrete values were defined for the attributes of the model and described by symbolic value scales expounded by words. These values were explicated based on the literature knowledge as well as expertise when deemed necessary. CESIM uses no more than a three-grade scale value (i.e., "Unfavorable", "Moderately favorable", and "Favorable") for the aggregated and basic attributes, which alludes to crop establishment. The value Favorable means that the attribute is favorable to seed germination, seedling emergence, stand uniformity (i.e., the uniformity of emerged seedlings in terms of growth stage, including height, biomass, stem diameter, and so on), and, finally, crop establishment.

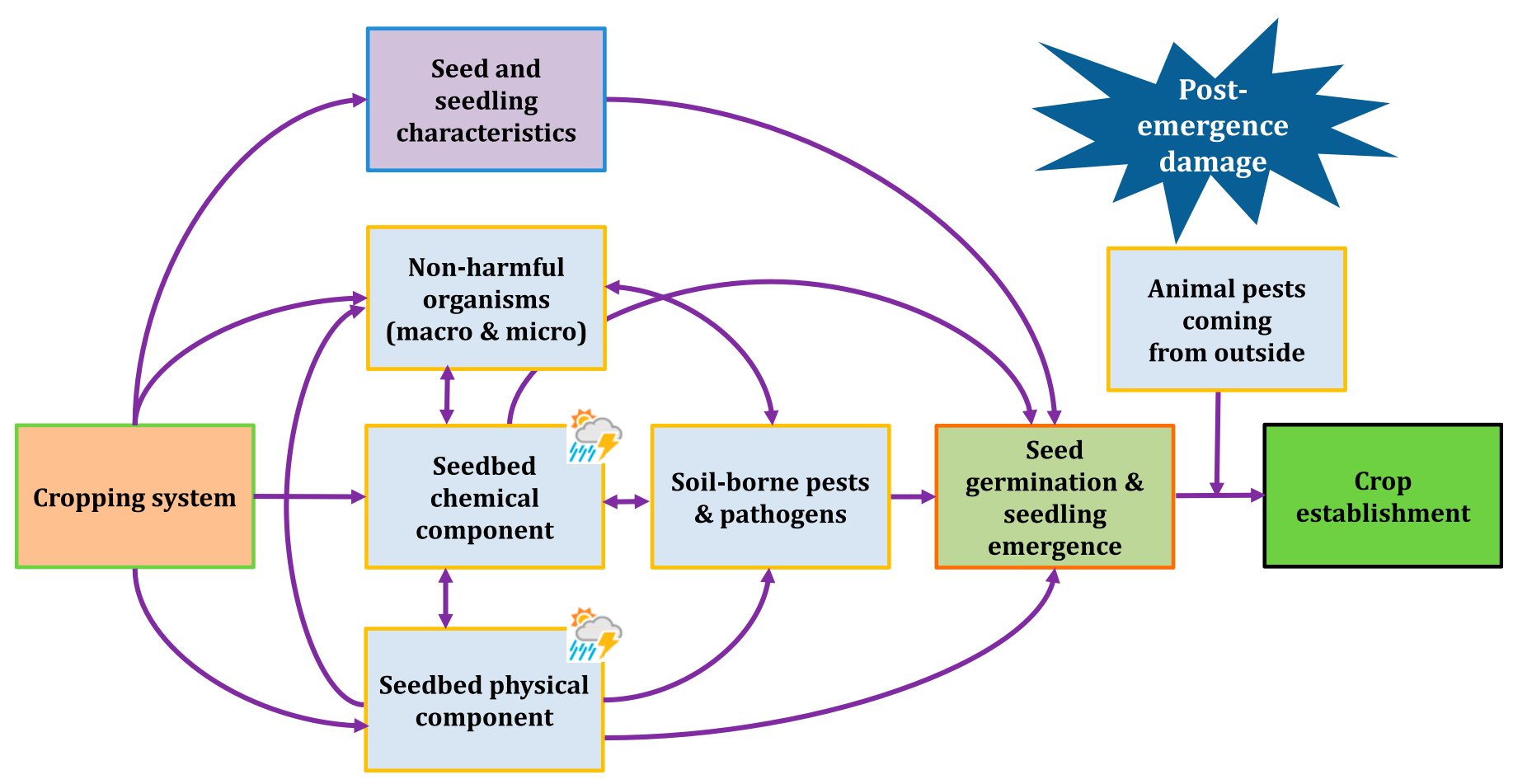

Fig. 1. Conceptual framework that highlights how each component of phytobiomes and their interactions affect field crop establishment (adapted from Lamichhane et al. 2018). Four major components of phytobiomes-namely, cropping system, seed and seedling characteristics, seedbed components (physical, chemical, and biological), and weather-as well as their interactions, affect seed germination, seedling emergence, and crop establishment. Postemergence seedling damage can be caused by soilborne pests and pathogens (internal component of the seedbed) or by animal pests coming from outside (external component of the seedbed such as birds, wild animals, and so on). Airborne pathogens are not included because their impact on crop growth and development is important only after the crop establishment phase and because all key pathogens affecting the crop establishment phase are soilborne (Lamichhane et al. 2017, 2020b; Rojas et al. 2016; You et al. 2017b). Likewise, weeds are excluded because their impact on crop growth, development, and yield is important only after the crop establishment phase, when they are sufficiently developed to compete with crops for light and nutrients (Chauhan and Johnson 2011). 
Different values for basic attributes can be specified using quantitative data, which are subsequently converted into qualitative values. For example, the seed mass, seedbed temperature, or moisture can be converted into qualitative values using literature references or expertise. This conversion takes into account not only

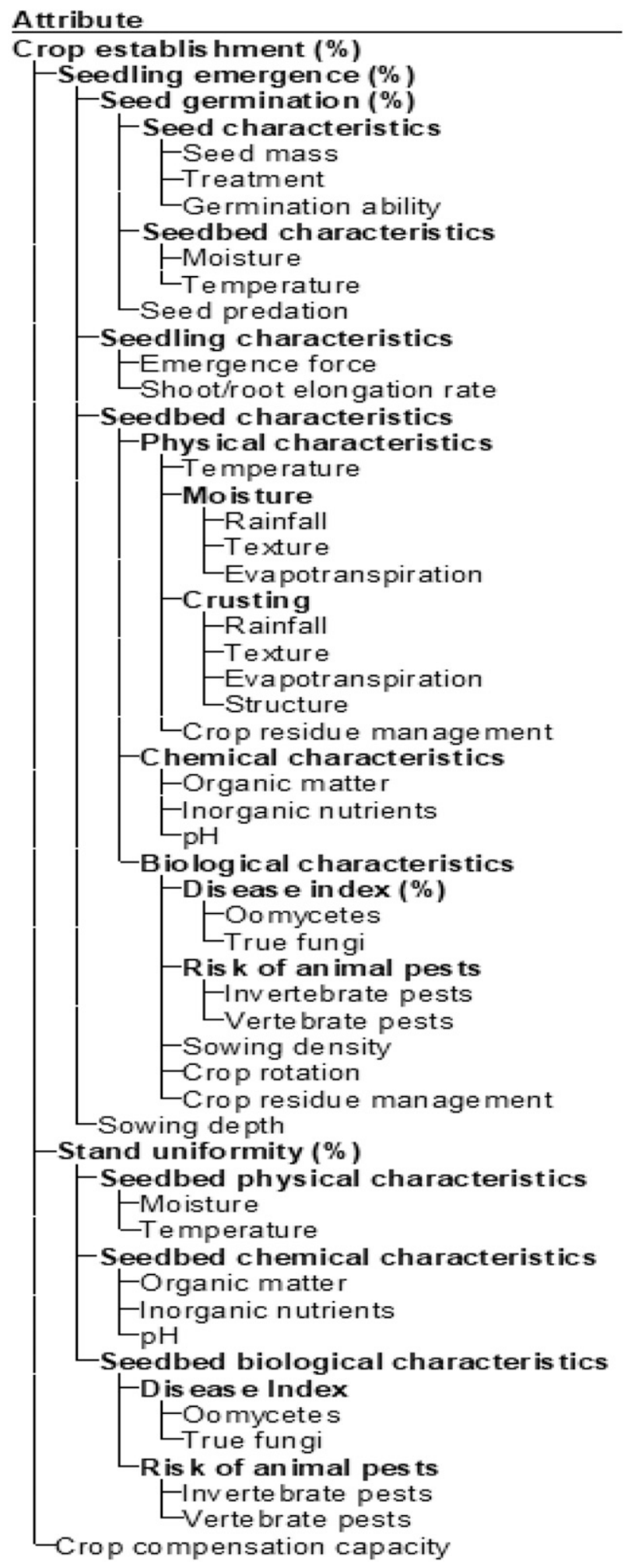

Fig. 2. Hierarchical structure of Crop Establishment SIMulator (screenshot of the DEXi software). Bold and nonbold terms represent aggregated and basic attributes, respectively. the regional context but also the crop in question. For instance, a relatively low seedbed moisture could be classified as Moderately favorable for oilseed rape or wheat (quite tolerant to water stress in the seedbed) but Unfavorable for soybean (very sensitive to water stress in the seedbed) establishment (Dürr et al. 2015; Lamichhane et al. 2020a). In contrast, other attributes, such as "crop rotation" or "crop residue management", can be directly described qualitatively.

For seed and seedling attributes, all characteristics provided by seed suppliers and, when available, those obtained by experimental results and from expertise can be used. Likewise, for the seedbed physical, chemical, and biological characteristics, the information can be retrieved from field experiments. Information related to weather attributes such as rainfall and evapotranspiration can be either measured using sensors or recovered from nearby meteorological stations. The scales, which are ordered from unpromising values to the propitious ones for crop establishment, are shown in Figure 3. All of these characteristics are clearly noticeable in the DEXi software as detrimental, neutral, and favorable values to the end user are, by convention, colored in red, black, and green, respectively.

Any initial quantitative or qualitative input attribute values can be converted into qualitative appreciation, based on two to three scales. These scales are defined relying on available information in the literature, models, or expertise. For the same attribute, a two-value scale (Unfavorable, and Favorable) was used for the seed germination and seedling emergence phase (e.g., temperature, moisture, and so on) while a three-value scale (Unfavorable, Moderately favorable, and Favorable) was used after seedling emergence (Fig. 3 ). This is because seed germination is, indeed, strongly affected by relatively high or low levels of seedbed temperature or moisture that have an important impact on seedling growth and stand uniformity that, together, determine the final crop establishment (Constantin et al. 2015).

Definition of aggregating tables. The choice of aggregating tables that determine the aggregation of attributes in the tree and their interactions is the third step in the design of a DEXi model. A set of "if-then" rules determines the value of the considered attribute, for each aggregated attribute in the model, as a function of the values of its immediate descendants in the model. The rules that correspond to a single aggregated attribute are assembled together and easily represented in tabular form. Each table defines a mapping of all value combinations of lower-level attributes into the values of the aggregate attribute. Decision rules that correspond to the "Seed germination" aggregated attribute and define the value of this attribute for the 12 possible combinations of the three seed characteristics, the two levels of seedbed characteristics, and the two levels of seed predation are shown in Figure 4. For example, if seed and seedbed characteristics are favorable and the seed predation rate is low, then the Seed germination will be high and, thus, favorable to crop establishment (Fig. 5).

All CESIM aggregating tables have been generated using literature, experimental data, and expert knowledge when deemed necessary. Other aggregating tables of the model are reported in Supplementary Figures S1 to S4.

Evaluation of the prediction quality of CESIM: The establishment of subterranean clover establishment in Australia as a case study. Description of the dataset. A detailed description of the dataset used to test the prediction quality of the model is presented in Supplementary Table S1. The quality of subterranean clover establishment over the last four decades has been severely affected across Western Australia (Burnett et al. 1994; Foster et al. 2017; O'Rourke et al. 2009), which has encouraged research to investigate the key underlying causes. Soilborne pathogens have been reported to cause severe economic losses, thereby threatening the viability of 
this forage crop (Barbetti et al. 2007; Barbetti et al. 1986; Wong et al. 1985a), and four major soilborne pathogens-namely, Phytophthora clandestina (Simpson et al. 2011; You and Barbetti 2017b; You et al. 2005b), Pythium irregulare (Wong et al. 1984, 1985b; You et al. 2017b), Rhizoctonia solani (Maughan and Barbetti 1983; Wong et al. 1985a; You and Barbetti 2017a; You et al. 2008), and Aphanomyces trifolii (Ma et al. 2008; You et al. 2016, 2018) - have been reported to cause root rot of subterranean clover. The severity of the disease caused by these soilborne pathogens mainly depends on cropping system (e.g., cultivar

\begin{tabular}{|c|c|}
\hline Attribute & Scale \\
\hline Crop e stablishment (\%) & Low (440); Mode rately low (40-60); Moderatel y high (60-80); High (>80) \\
\hline lling eme rgence (\%) & Low ( $<50)$; Medium $(50-70)$; High $(>70)$ \\
\hline ed germ ination (\%) & Low ( 40 ); Medium (70-90); High $(>90)$ \\
\hline - Se ed characte ris tics & Unfavorable; Moder ately faworable; Favorable \\
\hline - Seed mass & Small; Medum Large \\
\hline -Treatnent & NH-low effectivenes 5 ; High ef fectiveness \\
\hline LGermination ability & Low; Medum; High \\
\hline - Se edbed characte ris tics & Unfavorable; Favorable \\
\hline -Moisture & Unfavorable; Favorable \\
\hline L-Temper ature & Unfavorable; Favorable \\
\hline -Seed predation & High; Low \\
\hline Se edling characte ris tics & Unfavorable; Moder ately faworable; Favorable \\
\hline LEmergence force & Low; Medium; High \\
\hline Shootir oot ebngation rate & Low; Medium; High \\
\hline edbed characte ris tics & Unfavorable; Moder ately faworable; Favorable \\
\hline Physical characte ris tics & Unfavorable; Moder ately faworable; Favorable \\
\hline -Temper ature & Unfavorable; Moder ately faworable; Favorable \\
\hline -Moisture & Unfavorable; Moder ately faworable; Favorable \\
\hline -Rainfal & Unfavorable; Moder ately faworable; Favorable \\
\hline -Texture & Unfavorable; Favorable \\
\hline LEvapotranspiration & Unfavorable; Moder ately faworable; Favorable \\
\hline -Crusting & Unfavorable; Moder ately faworable; Favorable \\
\hline -Rainfal & Unfavorable; Moder ately faworable; Favorable \\
\hline -Texture & Unfavorable; Favorable \\
\hline -Evapot anspiration & Unfavorable; Moder ately faworable; Favorable \\
\hline LStructure & Unfavorable; Favorable \\
\hline Lorop residue nanagement & Unfavorable; Favorable \\
\hline Chem ical characteristics & Unfavorable; Moder ately faworable; Favorable \\
\hline -Organic natter & Unfavorable; Moder ately faworable; Favorable \\
\hline - horganic nutrents & Unfavorable; Favorable \\
\hline & Unfavorable; Favorable \\
\hline Eological characteristics & Unfavorable; Moder ately faworable; Favorable \\
\hline -Disease index $(\%)$ & Unfavorable; Moder ately faworable; Favorable \\
\hline -Oompetes & Unfavorable; Favorable \\
\hline LTrue fungi & Unfavorable; Favorable \\
\hline -Fisk of animal pests & Unfavorable; Moder ately faworable; Favorable \\
\hline -Invertebrate pests & Unfavorable; Favorable \\
\hline LVertebrate pests & Unfavorable; Favorable \\
\hline - Sow ing density & Unfavorable; Favorable \\
\hline - Orop rotation & Unfavorable; Favorable \\
\hline Lorop residue nanagement. & Unfavorable; Favorable \\
\hline ow ing depth & Poor; A ver age; Optimal \\
\hline and uniform ity $(\%)$ & Low ( $<50$ ); Medium (50-80); High (>80) \\
\hline eedbed phys ical characte ris tics & Unfavorable; Moder ately faworable; Favorable \\
\hline -Mosture & Unfavorable; Moder ately faworable; Favorable \\
\hline - Temperature & Unfavorable; Moder ately faworable; Favorable \\
\hline Se edbed chem ical characteristics & Unfavorable; Moder ately faworable; Favorable \\
\hline -Organic matter & Unfavorable; Moder ately faworable; Favorable \\
\hline - horgaric nutrients & Unfavorable; Moder ately faworable; Favorable \\
\hline & Unfavorable; Moder ately faworable; Favorable \\
\hline -Se edbed biological characte ris tics & Unfavorable; Moder ately faworable; Favorable \\
\hline -Dise ase Index & Unfavorable; Moder ately faworable; Favorable \\
\hline -Oomycetes & Unfavorable; Favorable \\
\hline LTrue fungi & Unfavorable; Favorable \\
\hline -Fsk of animal pests & Unfavorable; Moder ately faworable; Favorable \\
\hline -hvertebrate pests & Unfavorable; Moder ately faworable; Favorable \\
\hline LVertebrate pests & Unfavorable; Moder ately faworable; Favorable \\
\hline -Crop compensation capacity & Unfavorable; Moder ately faworable; Favorable \\
\hline
\end{tabular}

Fig. 3. Attribute scales of Crop Establishment SIMulator (screenshot of the DEXi software). Scales are ordered from unfavorable values for crop establishment (on the left-hand side) to favorable ones (on the right-hand side). This difference is clearly noticeable in the DEXi software because, by convention, values favorable to the user are colored in green, detrimental in red, and neutral in black. 
choice) or seedbed soil and weather characteristics (e.g., soil texture, structure, moisture, temperature, and rainfall) (Barbetti and MacNish 1984; Hochman et al. 1990; Wong et al. 1985a,b; You and Barbetti 2017a,b; You et al. 2017a,b). In addition, there are also other components affecting the quality of subterranean clover establishment such as the impact of animal pests such as nematodes (Barbetti et al. 2007; Pung et al. 1988).

Research conducted over the last four decades in Australia focused on a number of issues spanning from ecology and epidemiology of damping-off disease caused by soilborne pathogens (Barbetti et al. 1986; Sivasithamparam 1993; Wong et al. 1984, 1985a,b; You et al. 2008) to identification and deployment of available host resistance (Nichols et al. 2014, 2013; You et al. 2005a, 2016), use of mineral nutrients (O'Rourke et al. 2012), and soil and plant management (Smiley et al. 1986). More recent research has been aimed at better understanding of soil and weather effects and their interactions with cropping practices and the overall impact on disease development and levers toward better disease management (You and Barbetti 2017a, b; You et al. 2017a, b, 2018). All of this research conducted across Australia in the last four decades allowed us to generate an important amount of primary knowledge on how different factors and their interaction may affect the quality of subterranean clover establishment. Thus, this dataset represents an unprecedented opportunity for modeling frameworks.

The required datasets had to provide information for input attributes of CESIM (description of seed, seedling and seedbed characteristics, cropping practices, and climate) and its output (crop establishment), which was challenging. Therefore, the predictive quality of CESIM was tested using two kinds of dataset: (i) that originating from an Australia-wide survey that was carried out in 2014 to identify the quality of subterranean clover establishment across four states (South Australia, New South Wales, Victoria, and Western Australia) in Australia and (ii) that generated from different greenhouse and field trials conducted in Australia over the last four decades.

Although the model structure considers different levels of crop rotation or cropping practices, out dataset included only a low level of variability for some of the input variables. For example, subterranean clover is an annual pasture crop that naturally reseeds each growing season and, therefore, no crop rotation data were included in our dataset. Likewise, although most field crops are subjected to

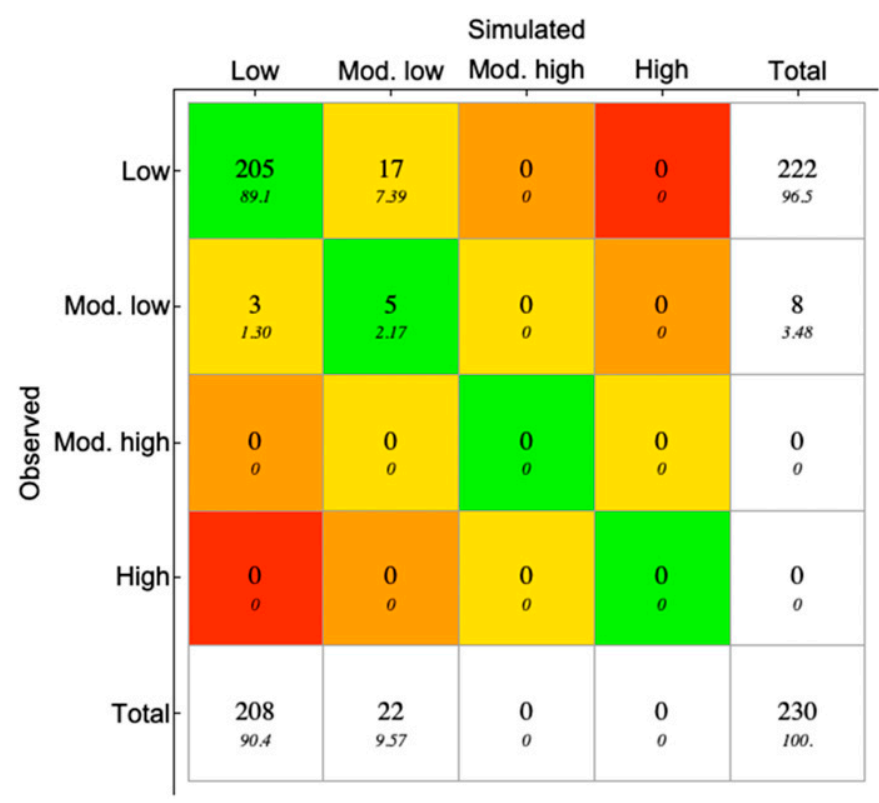

Fig. 5. Confusion matrix of the Crop Establishment SIMulatorSubterranean clover model and marginal distributions. Numbers in italics indicate overall percentages calculated as the ratio of the number of instances in a given situation, or marginal sums, to the total number of observations $\times 100(n=231)$. Green and red color codes indicate the minimum and maximum difference between observed and simulated values, respectively. Intermediate colors were arbitrarily defined by the ColorFunction option in Mathematica (Wolfram Research 2015), according to the number of the classes considered (four in this case). Mod. Low and Mod. High = moderately low and moderately high classes, respectively.

\section{Seed characteristics}

1 Unfavorable

2 Unfavorable

3 Unfavorable

4 Unfavorable

5 Moderately favorable

6 Moderately favorable

7 Moderately favorable

8 Moderately favorable

9 Favorable

10 Favorable

11 Favorable

12 Favorable
Seedbed characteristics Unfavorable Unfavorable Favorable Favorable Unfavorable Unfavorable Favorable Favorable Unfavorable Unfavorable Favorable Favorable

\begin{tabular}{|c|c|}
\hline Seed predation & Seed germination (\%) \\
\hline High & $\operatorname{Low}(<70)$ \\
\hline Low & Low $(<70)$ \\
\hline High & Low $(<70)$ \\
\hline Low & Low $(<70)$ \\
\hline High & Low $(<70)$ \\
\hline Low & Low $(<70)$ \\
\hline High & Low $(<70)$ \\
\hline Low & Medium (71-90) \\
\hline High & Low $(<70)$ \\
\hline Low & Low $(<70)$ \\
\hline High & Low $(<70)$ \\
\hline -ow & High $(>90)$ \\
\hline
\end{tabular}

Fig. 4. Aggregating table for the Seed germination aggregated attribute (screenshot of the DEXi software). Aggregation rules for the 12 possible combinations of the three seed characteristics, two levels of seedbed characteristics, and two levels of seed predation. 
seed treatment (Lamichhane et al. 2020b), no seed treatment was performed for subterranean clover for two reasons. First, this crop is considered a low-value crop and, second, damping-off disease limiting the establishment and productivity of this crop is most often caused not only by one soilborne pathogen but by a pathogen complex. In such a case, fungicide seed treatment is not effective in managing the disease (You et al. 2020). Nevertheless, all data used to assess the prediction quality of the model included information corresponding to the real field situations. In total, we used data collected across 231 production situations. All of these data were transformed into qualitative values and used as input basic attributes to feed CESIM-Subterranean clover.

Converter. As for any other DEXi-based models (Robin et al. 2018), CESIM-Subterranean clover is based on qualitative attributes and aggregative tables with nominal or quantitative variables. The latter are generally available for users dealing with their specific situations. A converter was designed to transform these variables into ordinal ones using specific regional references adapted to the local pedoclimatic situations and cropping practices. A detailed description of the converter used for this purpose is presented in Supplementary Table S2.

Simulations with DEXi. The qualitative final attribute value (final rate of crop establishment) is calculated by DEXi. The estimation consists of calculating all aggregated attribute values according to (i) the structure of the tree; (ii) the considered simulation unit, defined as a set of input variables (basic attribute values); and (iii) the aggregating tables for the aggregation of attributes.

Evaluation of the predictive quality of CESIM-Subterranean clover. CESIM was evaluated for its ability to predict crop establishment classes. To this end, quantitative observed values of crop establishment were transformed into ordinal values, using the same range as the model (i.e., 0 to 40,40 to 60,60 to 80 , and 80 to $100 \%$ ). Each of the observed crop establishment percentages was related to a value simulated by the model using the corresponding observed input attributes. To assess the predictive quality of the model, a confusion matrix was computed as a table layout, where each column represents the instances in a predicted class, while each row represents the instances in an observed class. Accuracy (proportion of correctly predicted situations) is a widely used performance metric. However, it cannot be the only statistical criterion to consider because our dataset is unbalanced. Both Matthews Correlation Coefficient (MCC) (Matthews 1975) and Cohen's quadratic weighted $\kappa$ (Cohen 1960; Fleiss and Cohen 1973) correct this bias but the former is preferred for unbalanced cases (Delgado and Tibau 2019). MCC is a special case of Pearson correlation coefficient and leads to similar interpretations (Matthews 1975). It takes into account true and false positives and negatives and is generally regarded as a balanced measure, which can be used even if the classes are of very different sizes. We also used the Cohen's quadratic weighted $\kappa$ because it can be interpreted as the proportion of variability explained by the model (Fleiss and Cohen 1973). The dataset used had only two classes of crop establishment quality: Low $(\leq 40 \%)$ and Moderately low (41 to $60 \%$ ). Therefore, two additional statistics for binary classifiers were also considered (Agresti 2002): the sensitivity (measurement of the proportion of situations with actual low crop establishment correctly predicted), and the specificity (measurement of the proportion of situations with moderately low crop establishment quality correctly predicted). These computations were carried out using Mathematica 10.1.0.0 (Wolfram Research 2015).

Sensitivity analysis. Sensitivity analysis was conducted using the automatic procedure integrated into the DEXi software (Bohanec 2009), which computes the standardized local and global weights of each attribute as a function of the aggregative tables using a linear regression method (Bohanec 2009). Previous studies that used DEXi-based models performed sensitivity analysis to measure the behavior of the model output against changes in parameters or other input values (Carpani et al. 2012; Robin et al. 2018). These weights are important because they are comparable with a sensitivity analysis for quantitative models (Robin et al. 2018). The higher the weight, the more influential the attribute. The "Local" and "Global" weights are calculated in two different ways. Local weights are assigned to each aggregated attribute individually so that the sum of weights of its immediate descendants in the hierarchy equals $100 \%$. The Global weights are determined at a given level of aggregation and signify the importance of each attribute on the value of the output attribute. The Global weights are computed by multiplying the Local weight of a given attribute at a given level of aggregation, by local weighting of its ascendants. Only standardized values are presented because nonstandardized weights calculated by DEXi do not take into account the number of classes in the scales used and prevent the structural bias they induce (Bohanec 2009).

\section{RESULTS}

Sensitivity analysis. The weights of each of the 58 attributes of the model are reported in Table 1, providing an overview of the model's structure. CESIM has five levels of aggregation (Fig. 3), the fifth one being the leaves (i.e., the model input basic attributes). For example, the output attribute "Final percentage of establishment" is defined at a level of $40 \%$ by the attribute "Seedling emergence", $20 \%$ by the attribute "Stand uniformity", and $40 \%$ by the attribute "Crop compensation capacity". As a proof of the complexity of the underlying processes at stake, the most influential input attribute (leaves), after the attribute "Crop compensation capacity" (40\%), is only 4\% (attribute "Seed predation").

Evaluation of the predictive quality of CESIM-Subterranean clover. The relatively high number of observed situations in the dataset (231) allowed an acceptable evaluation of the CESIMSubterranean clover predictive quality. The accuracy of the confusion matrix (Fig. 5) revealed that the model correctly predicted $91.3 \%$ of the observations (sum of the italic numbers reported in the diagonal of the matrix in green). However, the MCC (0.342) revealed a fair agreement as confirmed by the Cohen's $\kappa$ criterion (0.297) (Landis and Koch 1977). The model has a good sensitivity (0.62) and an excellent specificity (0.92). As expected, the predictive quality of the model was excellent for the lowest crop establishment class (i.e., the most frequently observed class in the dataset): $92 \%$ of the observed values between 0 and $40 \%$ were correctly simulated (as described by the specificity). Consequently, the overall predictive quality of CESIM-Subterranean clover was considered satisfactory.

\section{DISCUSSION}

Complexity of the crop establishment phase and the need for multidisciplinary research. The quality of crop establishment under field conditions is affected by several factors and their interactions, depending on cropping practices and production situations (Lamichhane et al. 2018). For example, drought represents the most important limiting factor to cover crop establishment in southern France (Constantin et al. 2015), whereas soilborne pathogens are the major limiting factor for the establishment of forage crops across Southern Australia (Barbetti et al. 2007; Foster et al. 2017; You and Barbetti 2017a, b; You et al. 2018). However, in both cases, these abiotic and biotic factors interact not only 
TABLE 1

Normalized attribute weights of Crop Establishment SIMulator-subterranean clover establishment computed by DEXi (Bohanec 2015) ${ }^{a}$

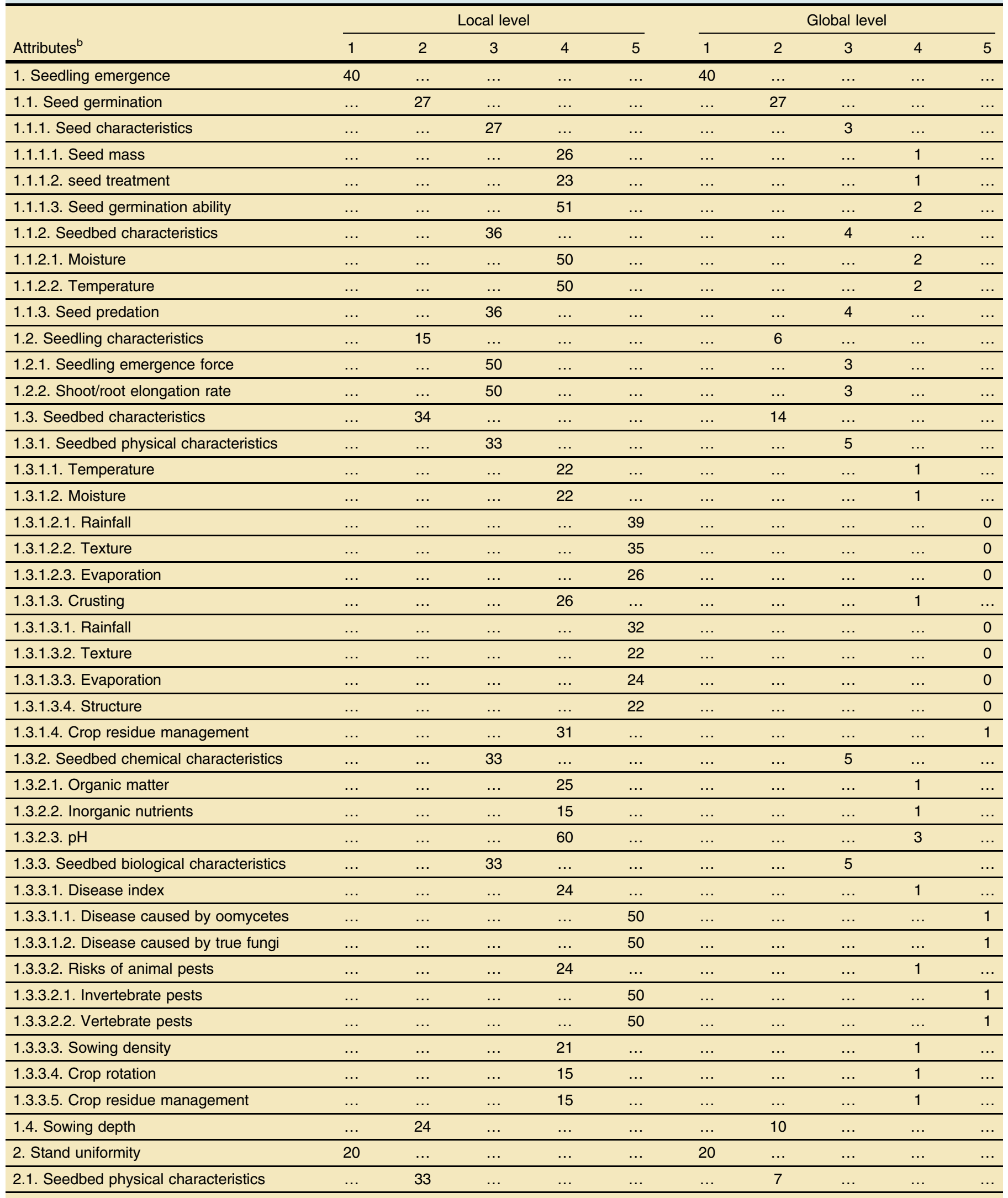

(Continued on next page)

\footnotetext{
a The impact of each attribute on the value of the immediate descendant attribute in the hierarchy is represented by Local weights while the influence of each attribute on the value of the final attribute is defined by Global weights. Local and Global weights are distributed in five levels of aggregation.

${ }^{b}$ Attributes defining the final percentage of subterranean clover establishment.
} 
TABLE 1 (Continued from previous page)

\begin{tabular}{|c|c|c|c|c|c|c|c|c|c|c|}
\hline \multirow[b]{2}{*}{ Attributes $^{b}$} & \multicolumn{5}{|c|}{ Local level } & \multicolumn{5}{|c|}{ Global level } \\
\hline & 1 & 2 & 3 & 4 & 5 & 1 & 2 & 3 & 4 & 5 \\
\hline 2.1.1. Moisture & $\ldots$ & $\ldots$ & 50 & $\ldots$ & $\ldots$ & $\ldots$ & $\ldots$ & 3 & $\ldots$ & $\ldots$ \\
\hline 2.2. Seedbed chemical characteristics & $\ldots$ & 33 & & $\ldots$ & $\ldots$ & $\ldots$ & 7 & $\ldots$ & $\ldots$ & $\ldots$ \\
\hline 2.2.1. Organic matter & $\ldots$ & $\ldots$ & 50 & $\ldots$ & $\ldots$ & $\ldots$ & $\ldots$ & 3 & $\ldots$ & $\ldots$ \\
\hline 2.2.3. $\mathrm{pH}$ & $\ldots$ & $\ldots$ & 25 & $\ldots$ & $\ldots$ & $\ldots$ & $\ldots$ & 2 & $\ldots$ & $\ldots$ \\
\hline 2.3. Seedbed biological characteristics & $\ldots$ & 33 & $\ldots$ & $\ldots$ & $\ldots$ & $\ldots$ & 7 & $\ldots$ & $\ldots$ & $\ldots$ \\
\hline 2.3.1. Disease index & $\ldots$ & $\ldots$ & 50 & $\ldots$ & $\ldots$ & $\ldots$ & $\ldots$ & 3 & $\ldots$ & $\ldots$ \\
\hline 2.3.1.1. Disease caused by oomycetes & $\ldots$ & $\ldots$ & $\ldots$ & 50 & $\ldots$ & $\ldots$ & $\ldots$ & $\ldots$ & 2 & $\ldots$ \\
\hline 2.3.1.2. Disease caused by true fungi & $\ldots$ & $\ldots$ & $\ldots$ & 50 & $\ldots$ & $\ldots$ & $\ldots$ & $\ldots$ & 2 & $\ldots$ \\
\hline 3. Crop compensation capacity & 40 & $\ldots$ & $\ldots$ & $\ldots$ & $\ldots$ & 40 & $\ldots$ & $\ldots$ & $\ldots$ & $\ldots$ \\
\hline
\end{tabular}

among themselves but also are under the influence of cropping practices that finally determine the quality of crop establishment. Focusing on only some of the factors determining the quality of crop establishment may not allow development of sustainable solutions. This is especially true when taking into account the complexity behind the crop establishment phase, requiring knowledge, and expertise from agronomy, phytopathology, entomology, weed science, soil science and soil microbial ecology. The modeling framework proposed herein is a telling example that highlights how a complex issue can be disentangled into more simple problems and how all of this can be addressed using a broader approach, integrating literature knowledge and expertise (notably from scientific specialists but also from farmers and agricultural advisers).

Potentials of CESIM generic modeling framework. Despite the availability of a rich dataset on factors affecting the establishment quality of subterranean clover, no modeling framework has been developed to date undertaking a systems approach. A small part of this dataset has been recently used to develop generalized linear models and boosted regression trees (You et al. 2017b, 2018) but these models did not take into account all key factors and their interactions. In addition, although these generalized linear models may have parameters with biological significance at discretion of the experts tuning or creating a model, this was not taken into account in these recent works. On the other hand, a quantitative modeling approach, such as the use of mechanistic models, is not realistic yet to study this complex system. This is because modelers need precise quantitative data on each variable of the model and their interactions, although they can still provide a good range of uncertainty around an estimation even without being fully calibrated (e.g., good sensitivity and uncertainty analysis procedures help in targeting the right parameters to accomplish it). Overall, a quantitative approach may lead to models difficult to use due to the challenge to provide input variables. Also, propagation errors are a common pitfall of complex mechanistic models. However, these issues can be overcome by using a qualitative generic modeling framework. The dataset and knowledge available on the agroecosystems with subterranean clover allowed us to test the prediction quality of a complex generic model such as CESIM, which is not yet possible for other crops due to incomplete data availability.

CESIM represents the first model that takes into account all key abiotic and biotic factors, as well as cropping practices affecting the establishment quality of a given crop. The example of modeling framework reported herein is innovative because it allows aggregation of key information from different sources (i.e., technical and scientific literature, expert knowledge, experimental data, or data from field diagnoses). In this way, a high level of complexity can be addressed, given that it deals with qualitative variables (sometimes derived from quantitative variables). Such a qualitative framework is very appropriate, while modeling complex systems for which a high precision level is not necessarily a prerequisite. Thus, the DEXi software offers a relevant environment for organizing the available knowledge and developing models. In addition, DEXibased models allow a high level of generality (Aubertot and Robin 2013; Robin et al. 2018). A major innovation of CESIM is its flexibility and adaptability because the model promptly integrates any variables at any time with the possibility of adjusting certain scales or aggregative rules. In addition, the simple and user-friendly DEXi interface is another key advantage of this approach, which represents a powerful communication and educational tool. Finally, as for any DEXi-based model, CESIM can be used across a wide range of situations to perform not only the ex-ante assessment of potential establishment quality of a given crop but also the ex-post assessment, taking into account any possible changes in cropping practices or seed and seedling as well as seedbed characteristics, thereby facilitating the decision-making process.

Limits of CESIM generic modeling framework. One of the limits of the CESIM approach is the high number of attributes and scales used in the model. This is due, in part, to the fact that the crop establishment phase is composed of three subphases (seed germination, seedling emergence, and crop uniformity). This means that the same attributes and their related variables repeat several times within these subphases. For instance, seedbed characteristics such as moisture and temperature appear throughout all three subphases. Likewise, seedbed physical, chemical, and biological characteristics appear during two phases (seedling emergence and seedling uniformity). All of this makes the model structure quite 
complicated. In addition, the scales used for each of the attributes that repeat throughout different subphases are not necessarily the same. This would further increase the complexity of aggregative tables, which would be more difficult to complete. This could be due to many factors, including (i) lack of knowledge in the literature, (ii) lack of consistency in experimental and observational results, or (iii) lack of consensus among experts on the potential effects of different factors, given that attributes and scales were selected from literature, experimental data, and expert knowledge. As a consequence, the model may not be able to integrate these factors. An example is the effect of seedbed temperature and moisture on disease severity index. Because different soilborne pathogens, including oomycetes (Simpson et al. 2011; You and Barbetti 2017b; You et al. 2017b) and true fungi (You and Barbetti 2017a; You et al. 2016), affect the establishment quality of subterranean clover, the ranges of soil moisture and temperature triggering their epidemics could be different. In addition, most often these pathogens are subjected to synergistic interactions that lead to disease complexes. However, although this latter information is not precisely integrated into the model due to poor knowledge and expertise available to date, model inputs representing the outcomes of such synergistic interactions were integrated into this CESIM approach and well represented by variables such as "seed germination ability" and "crop compensation ability".

Certain values of the basic indicators are difficult to estimate objectively. For instance, the role of beneficial organisms in the soil, in particular that of antagonist microorganisms, in reducing negative impact of soilborne pathogens is very difficult for users to measure. Consequently, we did not include this variable in the model. Nevertheless, this variable is somehow well represented in the model by the variable "organic matter", because soil organic matter has been reported to be directly correlated to disease suppressiveness due to the induction of physicochemical and biological changes in soils (Campos et al. 2016; Vida et al. 2020). This means that the higher the soil organic matter in the soil, the lower the risk of disease development due to soilborne pathogens. Likewise, the variable "crop rotation", which has been reported to enhance disease-suppressive potential in soils when diversified (Peralta et al. 2018), is also integrated into the model and, to some extent, represents the role of beneficial microorganisms. Another variable difficult to measure for users is "seed latently infected by seedborne pathogens", which depends on the seed quality and, thus, belongs to seed characteristics. Although we did not include this variable in the model, this characteristic is already well represented by the variables "seed germination ability" and "seed treatment". Indeed, the higher the percentage of latent seed infection in a given seed lot, the lower the germination ability if the seed are not treated. Finally, we did not include host resistance or tolerance into the model as a variable for either preemergence or postemergence. This is because the variables "seedling characteristics" and "crop compensation ability" represent host resistance or tolerance pre-and postemergence, respectively. This is more realistic than including specific host resistance as a variable for two reasons. First, no crop cultivar is fully resistant to all soilborne pathogens causing damping-off (Lamichhane et al. 2017) and a cultivar resistant to one soilborne pathogen can be susceptible to another soilborne pathogen or to a specific race of a given pathogen (Nichols et al. 2014; You et al. 2005a). Second, a resistant cultivar can rapidly become susceptible due to multiple resistance breaking as, for example, was the case for new races of Phytophthora clandestina (You et al. 2005a). In general, the variable "crop compensation ability" also includes any potential pre- or postemergence losses due to abiotic or biotic stresses via ramification, tillering, and indeterminate or semideterminate growth to ensure a good coverage of the seedbed.

In a qualitative model such as CESIM, the basic attribute values need to be defined qualitatively, and some of them have to originate from quantitative values with simple transformation. This operation can be time consuming, in some cases, especially when the number of attributes is high. In addition, such a procedure raises questions about the precision of the model, although the precision is not the main objective of such qualitative models (Aubertot and Robin 2013; Robin et al. 2018).

The results obtained when assessing the predictive quality of CESIM rely not only on the model itself but also on the diversity of the dataset. The more representative the data are of a range of soil, weather, cropping systems, and crop establishment, the more robust the evaluation. Although a relatively large dataset (i.e., 231 situations) was used to represent all of these variabilities, the dataset did not cover a wide range of situations. For instance, there was no variability in seed treatment (all nontreated seed), germination ability (all medium), seed predation (all low), evapotranspiration (all favorable), seedbed structure (all favorable), sowing density (all favorable), crop rotation (all unfavorable), sowing depth (all average), and vertebrate pests (all favorable). In addition, although four classes of the crop establishment quality were defined in the model, the dataset contained only low $(<40 \%)$ and moderately low (41 to $60 \%$ ) classes, while the other two classes (moderately high $=$ 61 to $80 \%$ and high $>80 \%$ ) were not represented in the dataset. Soilborne pathogens, in interaction with pedoclimatic factors, cropping practices, and production situations, cause devastating losses of subterranean clover across Australia (Barbetti et al. 1986, 2007). Disease management is extremely challenging for different reasons. First, host resistance is available to specific soilborne pathogens but not to all soilborne pathogen complexes (You et al. 2005a). Likewise, although chemical seed treatment is generally effective against individual pathogens, it is ineffective against pathogen complexes (You et al. 2020). Due to the permanent nature of annually self-regenerating subterranean clover forages, there is no crop rotation and, most often, farmers systematically tend to renovate semipermanent forages by making new sowings into preexisting clover fields that have severely declined. This makes clover establishment extremely challenging, because newly planted cultivars often fail to successfully establish within existing forage systems due to competition from the surviving seedbank. In addition, resowing new cultivars into a field already infected by soilborne pathogens can fail due to pre- and postemergence damping-off from soilborne pathogen complexes. All of this explains the frequently low to moderately low crop establishment rates in the dataset. This did not allow us to test the predictive quality of the model for relatively high or high rates of crop establishment.

Perspectives. Here, for the first time, we developed a qualitative modeling framework based on a systems approach that assesses the role of phytobiomes on field crop establishment. Development of such a model was a challenging task that has been achieved. The next step should focus on its improvement; in particular, to increase its predictive quality. For this objective, two approaches can be used: (i) optimization of the model by modifying the aggregative tables (equivalent to parameter optimization for quantitative models) (Aubertot and Robin 2013) and (ii) improvement of the dataset used herein to test the prediction quality of the model. The latter can be done by including those situations where the establishment quality of subterranean clover is high to very high in three different ways, as suggested previously (Robin et al. 2018): (i) setting up specific experiments, (ii) performing agronomic diagnoses in commercial fields, and (iii) integrating data from other countries. Also, the use of other simulation models could be 
considered in order to generate data, provided that their quality of prediction is sufficient.

\section{ACKNOWLEDGMENTS}

We thank G. Quesnel for his kind support and interaction on the model evaluation part; M.-H. Robin and D. C. Corrales for their suggestions on the DEXi-based modeling approach; and K. Guo, H. Bo, J. Quealy, K. Foster, D. Kidd, P. Skinner, P. Wilson, R. Creasy, and B. Piasini from the University of Western Australia for their technical support with collection of some data used in this modelling study.

\section{LITERATURE CITED}

Abdel-Monaim, M. F., and Abo-Elyousr, K. A. M. 2012. Effect of preceding and intercropping crops on suppression of lentil damping-off and root rot disease in New Valley - Egypt. Crop Prot. 32:41-46.

Agresti, A. 2002. Categorical Data Analysis, 2nd ed. Wiley Series in Probability and Mathematical Statistics. Wiley, Hoboken, NJ, U.S.A.

Anonymous. 2016. Phytobiomes: A Roadmap for Research and Translation. http://www.phytobiomes.org/Roadmap/Pages/default.aspx

Arvidsson, J., Etana, A., and Rydberg, T. 2014. Crop yield in Swedish experiments with shallow tillage and no-tillage 1983-2012. Eur. J. Agron. 52:307-315.

Aubertot, J.-N., Deguine, J.-P., Lamichhane, J. R., Robin, M.-H., Sarthou, J.-P., and Steinberg, C. 2020. Vers une protection agroécologique des cultures en phase d'implantation. Pages 107-134 in: Réussir l'Implantation Des Cultures. J. Boiffin, F. Laurent, and G. Richard, eds. (in French). Quæ, Versailles, France.

Aubertot, J.-N., and Robin, M.-H. 2013. Injury profile SIMulator, a qualitative aggregative modelling framework to predict crop injury profile as a function of cropping practices, and the abiotic and biotic environment. I. Conceptual bases. PLoS One 8:e73202.

Baker, R. 1971. Analyses involving inoculum density of soil-borne plant pathogens in epidemiology. Phytopathology 61:1280-1292.

Barbetti, M., You, M., Li, H., Ma, X., and Sivasithamparam, K. 2007. Management of root diseases of annual pasture legumes in Mediterranean ecosystems-A case study of subterranean clover root diseases in the south-west of Western Australia. Phytopathol. Mediterr. 46: 239-258.

Barbetti, M. J., and MacNish, G. C. 1984. Effects of cultivation and cultural practices on root rot of subterranean clover. Aust. J. Exp. Agric. Anim. Husb. 24:550-554.

Barbetti, M. J., Sivasithamparam, K., and Wong, D. 1986. Root rot of subterranean clover. Rev Plant Pathol 65:287-295.

Bayani, A., Tiwade, D., Dongre, A., Dongre, A. P., Phatak, R., and Watve, M. 2016. Assessment of crop damage by protected wild mammalian herbivores on the western boundary of Tadoba-Andhari Tiger Reserve (TATR), Central India. PLoS One 11:e0153854.

Bohanec, M. 2003. Decision support. Pages 23-35 in: Data Mining and Decision Support: Integration and Collaboration. The Springer International Series in Engineering and Computer Science book series (SECS, volume 745). D. Mladenić, N. Lavrač, M. Bohanec, and S. Moyle, eds. Springer, Boston, MA, U.S.A.

Bohanec, M. 2009. DEXi: Program for Multi-Attribute Decision Making, Version 3.02. Jozef Stefan Institute, Ljubljana, Slovenia.

Bohanec, M. 2015. DEXi: Program for Multi-Attribute Decision Making, User's Manual, Version 5.00. IJS Report DP-11897. Jožef Stefan Institute, Ljubljana, Slovenia. http://kt.ijs.si/MarkoBohanec/pub/ DEXiManual500.pdf

Bohanec, M., Cortet, J., Griffiths, B., Žnidaršič, M., Debeljak, M., Caul, S., Thompson, J., and Krogh, P. H. 2007. A qualitative multi-attribute model for assessing the impact of cropping systems on soil quality. Pedobiologia (Jena) 51:239-250.

BSV. 2016. Résultats de l'enquête dégâts de mouche (géomyze) sur maïs en Bretagne. Bulletin de Santé vegetal (in French). http://draaf.bretagne.agriculture. gouv.fr/IMG/pdf/Enquete-geomyze2016_cle887449.pdf

Burdon, J. J., and Chilvers, G. A. 1975. Epidemiology of damping-off disease (Pythium irregulare) in relation to density of Lepidium sativum seedlings. Ann. Appl. Biol. 81:135-143.

Burnett, V. F., Coventry, D. R., Hirth, J. R., and Greenhalgh, F. C. 1994. Subterranean clover decline in permanent pastures in north-eastern Victoria. Plant Soil 164:231-241.
Campos, S. B., Lisboa, B. B., Camargo, F. A. O., Bayer, C., Sczyrba, A., Dirksen, P., Albersmeier, A., Kalinowski, J., Beneduzi, A., Costa, P. B., Passaglia, L. M. P., Vargas, L. K., and Wendisch, V. F. 2016. Soil suppressiveness and its relations with the microbial community in a Brazilian subtropical agroecosystem under different management systems. Soil Biol. Biochem. 96:191-197.

Carpani, M., Bergez, J. E., and Monod, H. 2012. Sensitivity analysis of a hierarchical qualitative model for sustainability assessment of cropping systems. Environ. Model. Softw. 27-28:15-22.

Chauhan, B. S., and Johnson, D. E. 2011. Row spacing and weed control timing affect yield of aerobic rice. Field Crops Res. 121:226-231.

Chauhan, B. S., and Opeña, J. 2013. Implications of plant geometry and weed control options in designing a low-seeding seed-drill for dry-seeded rice systems. Field Crops Res. 144:225-231.

Cohen, J. 1960. A coefficient of agreement for nominal scales. Educ. Psychol. Meas. 20:37-46.

Constantin, J., Dürr, C., Tribouillois, H., and Justes, E. 2015. Catch crop emergence success depends on weather and soil seedbed conditions in interaction with sowing date: A simulation study using the SIMPLE emergence model. Field Crops Res. 176:22-33.

Craheix, D., Bergez, J.-E., Angevin, F., Bockstaller, C., Bohanec, M., Colomb, B., Doré, T., Fortino, G., Guichard, L., Pelzer, E., Méssean, A., Reau, R., and Sadok, W. 2015. Guidelines to design models assessing agricultural sustainability, based upon feedbacks from the DEXi decision support system. Agron. Sustain. Dev. 35:1431-1447.

Delgado, R., and Tibau, X.-A. 2019. Why Cohen's Kappa should be avoided as performance measure in classification. PLoS One 14:e0222916.

Dimitri, G., Yuri, V., Albores-Barajas, N., Emilio, B., Lorenzo, V., and Cecilia, S. 2012. Feral pigeons: Problems, dynamics and control methods. Pages 215-240 in: Integrated Pest Management and Pest Control—Current and Future Tactics. S. Soloneski, ed. InTech, Rijeka, Croatia.

Dürr, C., and Aubertot, J.-N. 2000. Emergence of seedlings of sugar beet (Beta vulgaris $\mathrm{L}$.) as affected by the size, roughness and position of aggregates in the seedbed. Plant Soil 219:211-220.

Dürr, C., Aubertot, J. N., Richard, G., Dubrulle, P., Duval, Y., and Boiffin, J. 2001. SIMPLE: A model for simulation of plant emergence predicting the effects of soil tillage and sowing operations. Soil Sci. Soc. Am. J. 65:414-423.

Dürr, C., Dickie, J. B., Yang, X.-Y., and Pritchard, H. W. 2015. Ranges of critical temperature and water potential values for the germination of species worldwide: Contribution to a seed trait database. Agric. For. Meteorol. 200: 222-232.

Farooq, M., Barsa, S. M. A., and Wahid, A. 2006. Priming of field-sown rice seed enhances germination, seedling establishment, allometry and yield. Plant Growth Regul. 49:285-294.

Finch-Savage, W. E., Rowse, H. R., and Dent, K. C. 2005. Development of combined imbibition and hydrothermal threshold models to simulate maize (Zea mays) and chickpea (Cicer arietinum) seed germination in variable environments. New Phytol. 165:825-838.

Firake, D. M., Behere, G. T., and Chandra, S. 2016. An environmentally benign and cost-effective technique for reducing bird damage to sprouting soybean seeds. Field Crops Res. 188:74-81.

Fleiss, J. L., and Cohen, J. 1973. The equivalence of weighted kappa and the intraclass correlation coefficient as measures of reliability. Educ. Psychol. Meas. 33:613-619.

Forcella, F., Arnold, R. L. B., Sanchez, R., and Ghersa, C. M. 2000. Modeling seedling emergence. Field Crops Res. 67:123-139.

Foster, K., You, M. P., Nietschke, B., Edwards, N., and Barbetti, M. J. 2017. Widespread decline of subterranean clover pastures across diverse climatic zones is driven by soilborne root disease pathogen complexes. Crop Pasture Sci. 68:33-44.

Furlan, L., Benvegnù, I., Chiarini, F., Loddo, D., and Morari, F. 2020. Meadowploughing timing as an integrated pest management tactic to prevent soil-pest damage to maize. Eur. J. Agron. 112:125950.

Grogan, R. G., Sall, M. A., and Punja, Z. K. 1980. Concepts for modelling root infection by soilborne fungi. Phytopathology 70:361-363.

Hochman, Z., Osborne, G. J., Taylor, P. A., and Cullis, B. 1990. Factors contributing to reduced productivity of subterranean clover (Trifolium subterraneum L.) pastures on acidic soils. Aust. J. Agric. Res. 41:669-682.

Hwang, S. F., Ahmed, H., and Turnbull, G. D. 2008. Effect of crop rotation on canola seedling blight and soil pathogen population dynamics. Can. J. Plant Pathol. 30:369.

Jame, Y. W., and Cutforth, H. W. 2004. Simulating the effects of temperature and seeding depth on germination and emergence of spring wheat. Agric. For. Meteorol. 124:207-218. 
Känkänen, H., Alakukku, L., Salo, Y., and Pitkänen, T. 2011. Growth and yield of spring cereals during transition to zero tillage on clay soils. Eur. J. Agron. $34: 35-45$.

Lamichhane, J. R., and Aubertot, J.-N. 2018. A conceptual framework to better understand interactions between seedbed abiotic and biotic factors under the influence of cropping systems and their overall impact on field crop establishment. Page 31 in: Int. Phytobiomes Conf. 4th-6th December. Montpellier, France.

Lamichhane, J. R., Constantin, J., Schoving, C., Maury, P., Debaeke, P., Aubertot, J.-N., and Dürr, C. 2020a. Analysis of soybean germination, emergence, and prediction of a possible northward establishment of the crop under climate change. Eur. J. Agron. 113:125972.

Lamichhane, J. R., Debaeke, P., Steinberg, C., You, M. P., Barbetti, M. J., and Aubertot, J.-N. 2018. Abiotic and biotic factors affecting crop seed germination and seedling emergence: A conceptual framework. Plant Soil 432:1-28.

Lamichhane, J. R., Dürr, C., Schwanck, A. A., Robin, M.-H., Sarthou, J.-P., Cellier, V., Messéan, A., and Aubertot, J.-N. 2017. Integrated management of damping-off diseases. A review. Agron. Sustain. Dev. 37:10.

Lamichhane, J. R., You, M. P., Laudinot, V., Barbetti, M. J., and Aubertot, J. N. 2020b. Revisiting sustainability of fungicide seed treatments for field crops. Plant Dis. 104:610-623.

Landis, J. R., and Koch, G. G. 1977. The measurement of observer agreement for categorical data. Biometrics 33:159-174.

Leach, J. E., Triplett, L. R., Argueso, C. T., and Trivedi, P. 2017. Communication in the Phytobiome. Cell 169:587-596.

Leoni, C., de Vries, M., ter Braak, C. J. F., van Bruggen, A. H. C., and Rossing, W. A. H. 2013. Fusarium oxysporum f. sp. cepae dynamics: In-plant multiplication and crop sequence simulations. Eur. J. Plant Pathol. 137: 545-561.

Ma, X., Li, H., O’Rourke, T., Sivasithamparam, K., and Barbetti, M. J. 2008. Co-occurrence of an Aphanomyces sp. and Phytophthora clandestina in subterranean clover pastures in the high rainfall areas of the lower south-west of Western Australia. Australas. Plant Pathol. 37:74-78.

Matthews, B. W. 1975. Comparison of the predicted and observed secondary structure of T4 phage lysozyme. Biochim. Biophys. Acta Protein Struct. 405: 442-451.

Maughan, R. D., and Barbetti, M. J. 1983. Rhizoctonia root rot of white clover. Australas. Plant Pathol. 12:13-14.

Meynard, J. M., Doré, T., and Lucas, P. 2003. Agronomic approach: Cropping systems and plant diseases. C. R. Biol. 326:37-46.

Nasu, H., and Matsuda, L. 1976. The damage to soybean by pigeons and doves and its control methods. Agric. Hortic. 51:563-566.

Nichols, P. G. H., Foster, K. J., Piano, E., Pecetti, L., Kaur, P., Ghamkhar, K., and Collins, W. J. 2013. Genetic improvement of subterranean clover (Trifolium subterraneum L.). 1. Germplasm, traits and future prospects. Crop Pasture Sci. 64:312-346.

Nichols, P. G. H., Jones, R. A. C., Ridsdill-Smith, T. J., and Barbetti, M. J. 2014. Genetic improvement of subterranean clover (Trifolium subterraneum L.). 2. Breeding for disease and pest resistance. Crop Pasture Sci. 65:1207-1229.

O’Rourke, T. A., Ryan, M. H., Scanlon, T. T., Sivasithamparam, K., and Barbetti, M. J. 2012. Amelioration of root disease of subterranean clover (Trifolium subterraneum) by mineral nutrients. Crop Pasture Sci. 63:672-682.

O'Rourke, T. A., Scanlon, T. T., Ryan, M. H., Wade, L. J., McKay, A. C., Riley, I. T., Li, H., Sivasithamparam, K., and Barbetti, M. J. 2009. Severity of root rot in mature subterranean clover and associated fungal pathogens in the wheatbelt of Western Australia. Crop Pasture Sci. 60:43-50.

Pelzer, E., Fortino, G., Bockstaller, C., Angevin, F., Lamine, C., Moonen, C., Vasileiadis, V., Guérin, D., Guichard, L., Reau, R., and Messéan, A. 2012. Assessing innovative cropping systems with DEXiPM, a qualitative multicriteria assessment tool derived from DEXi. Ecol. Indic. 18:171-182.

Peralta, A. L., Sun, Y., McDaniel, M. D., and Lennon, J. T. 2018. Crop rotational diversity increases disease suppressive capacity of soil microbiomes. Ecosphere 9:e02235.

Pung, S. H., Barbetti, M. J., and Sivasithamparam, K. 1988. Association of Meloidogyne arenaria with root rot of subterranean clover in Western Australia. N. Z. J. Exp. Agric. 16:91-96.

Robin, M.-H., Bancal, M.-O., Cellier, V., Délos, M., Felix, I., Launay, M., Magnard, A., Olivier, A., Robert, C., Rolland, B., Sache, I., and Aubertot, J.-N. 2018. IPSIM-Web, an online resource for promoting qualitative aggregative hierarchical network models to predict plant disease risk: Application to brown rust on wheat. Plant Dis. 102:488-499.

Robin, M.-H., Colbach, N., Lucas, P., Montfort, F., Cholez, C., Debaeke, P., and Aubertot, J.-N. 2013. Injury profile SIMulator, a qualitative aggregative modelling framework to predict injury profile as a function of cropping practices, and abiotic and biotic environment. II. Proof of concept: Design of IPSIM-wheat-eyespot. PLoS One 8:e75829.

Rojas, J. A., Jacobs, J. L., Napieralski, S., Karaj, B., Bradley, C. A., Chase, T., et al. 2016. Oomycete species associated with soybean seedlings in North America-Part II: Diversity and ecology in relation to environmental and edaphic factors. Phytopathology 107:293-304.

Sadok, W., Angevin, F., Bergez, J.-E., Bockstaller, C., Colomb, B., Guichard, L., Reau, R., Messéan, A., and Doré, T. 2009. MASC, a qualitative multiattribute decision model for ex ante assessment of the sustainability of cropping systems. Agron. Sustain. Dev. 29:447-461.

Sausse, C., Lecomte, V., Martin-Monjaret, C., Raimbault, J., and Vogrincic, C. 2016. Dégâts d'oiseaux et petits gibiers-Synthèse de l'enquête Terres Inovia (in French).

Sausse, C., and Lévy, M. Dégâts d'oiseaux au tournesol: Situation internationale et perspectives. OCL. In press. (in French).

Sebillotte, M. 1974. Agronomie et agriculture, analyse des tâches de l'agronome. Cah. ORSTOM Ser. Biol. 24:3-25 (in French).

Sebillotte, M. 1990. Système de culture, un concept opératoire pour les agronomes. Pages 165-196 in: Les Systèmes de Culture. L. Combe and D. Picard, eds. INRA, Versailles, France (in French)

Simpson, R. J., Richardson, A. E., Riley, I. T., McKay, A. C., McKay, S. F., Ballard, R. A., Ophel-Keller, K., Hartley, D., O’Rourke, T. A., Li, H., Sivasithamparam, K., Ryan, M. H., and Barbetti, M. J. 2011. Damage to roots of Trifolium subterraneum L. (subterranean clover), failure of seedlings to establish and the presence of root pathogens during autumn-winter. Grass Forage Sci. 66:585-605.

Sivasithamparam, K. 1993. Ecology of root-infecting pathogenic fungi in Mediterranean environments. Adv. Plant Pathol. 10:245-279.

Smiley, R. W., Taylor, P. A., Clarke, R. G., Greenhalgh, F. C., and Trutmann, P. 1986. Simulated soil and plant management effects on root rots of subterranean clover. Aust. J. Agric. Res. 37:633-645.

Souty, N., and Rode, C. 1993. Emergence of sugar beet seedlings from under different obstacles. Eur. J. Agron. 2:213-221.

Vida, C., de Vicente, A., and Cazorla, F. M. 2020. The role of organic amendments to soil for crop protection: Induction of suppression of soilborne pathogens. Ann. Appl. Biol. 176:1-15.

Villalobos, F. J., Orgaz, F., and Fereres, E. 2016. Sowing and planting. Pages 217-227 in: Principles of Agronomy for Sustainable Agriculture. F. J. Villalobos and E. Fereres, eds. Springer International Publishing, Cham, Switzerland.

Wang, H., Cutforth, H., McCaig, T., McLeod, G., Brandt, K., Lemke, R., Goddard, T., and Sprout, C. 2009. Predicting the time to 50\% seedling emergence in wheat using a Beta model. NJAS Wagening. J. Life Sci. 57:65-71.

Wolfram Research. 2015. Mathematica, version 10.1.0.0 (Mac OS X x86 platform). Wolfram Research, Inc., Champaign, IL, U.S.A.

Wong, D. H., Barbetti, M. J., and Sivasithamparam, K. 1984. Effects of soil temperature and moisture on the pathogenicity of fungi associated with root rot of subterranean clover. Aust. J. Agric. Res. 35:675-684.

Wong, D. H., Barbetti, M. J., and Sivasithamparam, K. 1985a. Pathogenicity of Rhizoctonia spp. associated with root rots of subterranean clover. Trans. Br. Mycol. Soc. 85:156-158.

Wong, D. H., Barbetti, M. J., and Sivasithamparam, K. 1985b. Fungi associated with root rot of subterranean clover in Western Australia. Aust. J. Exp. Agric. 25:574-579.

You, M. P., Barbett, M. J., and Nichols, P. G. H. 2005a. New sources of resistance identified in Trifolium subterraneum breeding lines and cultivars to root rot caused by Fusarium avenaceum and Pythium irregulare and their relationship to seedling survival. Australas. Plant Pathol. 34:237-244.

You, M. P., and Barbetti, M. J. 2017a. Environmental factors determine severity of Rhizoctonia damping-off and root rot in subterranean clover. Australas. Plant Pathol. 46:357-368.

You, M. P., and Barbetti, M. J. 2017b. Severity of phytophthora root rot and preemergence damping-off in subterranean clover influenced by moisture, temperature, nutrition, soil type, cultivar and their interactions. Plant Pathol. 66:1162-1181.

You, M. P., Barbetti, M. J., and Sivasithamparam, K. 2005b. Characterization of Phytophthora clandestina races on Trifolium subterraneum in Western Australia. Eur. J. Plant Pathol. 113:267-274.

You, M. P., Guo, K., Nicol, D., Kidd, D., Ryan, M. H., Foster, K., and Barbetti, M. J. 2017a. Cultivation offers effective management of subterranean clover damping-off and root disease. Grass Forage Sci. 72:785-793.

You, M. P., Lamichhane, J. R., Aubertot, J.-N., and Barbetti, M. J. 2020. Understanding why effective fungicides against individual soilborne pathogens are ineffective with soilborne pathogen complexes. Plant Dis. 104:904-920.

You, M. P., Lancaster, B., Sivasithamparam, K., and Barbetti, M. J. 2008. Crosspathogenicity of Rhizoctonia solani strains on pasture legumes in pasturecrop rotations. Plant Soil 302:203-211. 
You, M. P., O'Rourke, T. A., Foster, K., Snowball, R., and Barbetti, M. J. 2016. Host resistances to Aphanomyces trifolii root rot of subterranean clover: First opportunity to successfully manage this severe pasture disease. Plant Pathol. 65:901-913.

You, M. P., Rensing, K., Renton, M., and Barbetti, M. J. 2017b. Modeling effects of temperature, soil, moisture, nutrition and variety as determinants of severity of Pythium damping-off and root disease in subterranean clover. Front. Microbiol. 8:2223.

You, M. P., Rensing, K., Renton, M., and Barbetti, M. J. 2018. Critical factors driving Aphanomyces damping-off and root disease in clover revealed and explained using linear and generalized linear models and boosted regression trees. Plant Pathol. 67:1374-1387. 